\title{
PENGKAJIAN SUHU RUANG PENYIMPANAN DAN TEKNIK PENGEMASAN TERHADAP KUALITAS BENIH KEDELAI
}

\author{
Indartono \\ Program Diploma III Teknik Mesin \\ Fakultas Teknik Universitas Diponegoro
}

\begin{abstract}
Indartono, in this paper explain that soybean seed quality decline if easy packaging and storage techniques are not good. This research aims to study the technique of packing and room temperature on soybean seed quality during the four months of storage. Research conducted at the Laboratory of Postharvest and Alsintan, BPTP Central Java, with a Completely Randomized Design 3 (three) factors and two replications. The first factor varieties (Burangrang, Willis, and Baluran), the second factor technique packaging (vacuum and without vacuum), and the third factor storage temperature $\left(27-29^{\circ} \mathrm{C}\right.$ and $\left.6^{\circ} \mathrm{C}\right)$. During the four storage observed changes in water content, shrinkage and the weight of soybean seed germination. The results showed that the shrinkage weight, water content and temperature of storage space does not give real effect to the power of germination for 4 four months of storage, and storage techniques vacuum (vacuum) to give an average power of germination is higher than without vacuum treatment, but a statistically not significantly different from other treatments by Duncan's test $95 \%$ confidence level for all varieties
\end{abstract}

Key words: soybean, room temperature storage, packaging techniques, the germinated

\section{PENDAHULUAN}

Kebutuhan Kedelai Nasional sangat tinggi, bahkan harus mengimport dari Amerika, oleh karenanya diperlukan peningkatan produktifitas kedelai Nasional. Berkaitan dengan hal tersebut, maka dibutuhkan benih kedelai yang berkualitas serta mempunyai daya kecambah yang baik. Kedelai (Glycerin max, L) merupakan salah satu jenis kacangkacangan yang banyak dikonsumsi oleh masyarakat Indonesia. Oleh karena itu peningkatan produksi kedelai dalam negeri harus ditingkatkan, karena sebagian besar kedelai yang digunakan adalah impor. Salah satu kelemahan produksi kedelai adalah masalah penyimpanan. Penyimpanan kedelai terutama untuk tujuan benih saat ini masih merupakan masalah yang perlu dipecahkan karena proses kemunduran benih kedelai selama penyimpanan berlangsung cepat, sehingga mengurangi penyediaan benih yang bermutu. Benih yang bermutu mempunyai sifat fisiologis, fisik dan genetik yang baik, yang dipengaruhi oleh proses produksi sampai penyimpanan (Sadjad, 1980). Pengadaan benih kedelai tepat jumlah dan waktu sering terkendala oleh daya simpan benih yang rendah (Purwanti, 2004). Pengadaan benih dilakukan beberapa waktu sebelum musim tanam dimulai, sehingga benih terlebih dahulu harus disimpan dengan baik agar mempunyai daya tumbuh yang optimal saat ditaman kembali.

Penurunan kualitas benih kedelai selama penyimpanan disebabkan oleh kandungan protein dan lemak dalam biji yang relatif tinggi, kadar air benih meningkat jika suhu dan kelembaban ruang simpan relative tinggi. Penurunan kualitas ini merupakan proses penurunan mutu yang berangsur-angsur dan kumulatif, serta tidak dapat balik akibat perubahan fisiologis dan biokimia ( Tatipata, et al; 2004 dan Purwanti, 2004). Kemunduran fisiologis benih dengan adanya penurunan viabilitas benih. Menurut Copeland, dkk (1985) faktor yang mempengaruhi viabilitas benih selama penyimpanan adalah faktor dari dalam ( sifat genetic, daya berkecambah dan vigor), dan faktor dari luar (kemasan benih, komposisi gas, suhu dan kelembaban ruang penyimpanan). Hal ini sejalan dengan pandapat Kartono (2004) yang menyatakan bahwa suhu penyimpanan berpengaruh terhadap daya berkecambah benih kedelai. Sedangkan kemunduran biokimia cirinya antara lain penurunan aktivitas enzim, cadangan makanan, dan meningkatnya nilai konduktivitas. Untuk itu perlu pencegahan peningkatan kadar air selama penyimpanan, yaitu dengan tehnik penyimpanan dengan bahan kemasan baik. Pentingnya mutu benih sebelum disimpan berkaitan erat dengan teknologi produksi benih. Benih kedelai yang baru dipanen dan disimpan dalam jangka waktu tertentu harus mempunyai daya berkecambah diatas 85\% (Rumiati et al, 1993).

Suhu ruang simpan berperan dalam mempertahankan viabilitas benih selama penyimpanan, yang dipengaruhi oleh kadar air benih, suhu dan kelembaban nisbi ruangan. Pada suhu rendah, respirasi berjalan lambat dibanding suhu tinggi. Dalam kondisi tersebut, viabilitas benih dapat dipertahankan lebih lama. Kadar air yang aman untuk penyimpanan benih kedelai dalam suhu kamar selama 6-10 bulan adalah tidak lebih dari 11\%. Menurut 
Harrington (1972), masalah yang dihadapi dalam penyimpanan benih makin kompleks sejalan dengan meningkatnya kadar air benih. Penelitian ini bertujuan untuk mengetahui pengaruh tehnik pengemasan dan suhu penyimpanan terhadap daya simpan benih kedelai setiap bulan selama empat bulan penyimpanan.

\section{BAHAN DAN METODE}

Bahan yang digunakan dalam penelitian ini adalah biji kedelai varietas Wilis, Burangrang, dan Baluran yang berasal dari Kabupaten Kabupaten Semarang, kantong plastic dengan ketebalan 0,8 mm, kapas, dan air. Adapun alat yang digunakan adalah moistertester, oven (pengukuran kadar air), spray, penjebit, cawan petri, dan bak perkecambahan.

\section{Rancangan percobaan}

Penelitian dilaksanakan dengan metode eksperimental, Rancangan Acak Lengkap 3 (tiga) factor dan 2 (dua) ulangan. Faktor pertama adalah suhu penyimpanan $\left(\mathrm{C} 1=\right.$ suhu kamar, yaitu $30^{\circ} \mathrm{C}$ dan $\mathrm{C} 2=$ suhu dingin, yaitu $10^{\circ} \mathrm{C}$ ), factor kedua adalah tekhik pengemasan $(\mathrm{P} 1=$ pengemasan dengan plastic tanpa perlakuan vakum dan $\mathrm{P} 2=$ pengemasan dengan plastic dengan perlakuan vakum), serta factor ketiga yaitu varietas kedelai (S1= varietas Burangrang, S2= varietas Wilis, dan $\mathrm{S} 3=$ varietas Baluran).

\section{Pelaksanaan penelitian}

Penelitian dilaksanakan di Laboratorium Pascapanen dan Alsintan, Balai Pengkajian Teknologi Jawa Tengah, pada bulan Januari 2010 - Juni 2010. Biji kedelai calon benih dikeringkan dengan cara dijemur sampai kadar air 10\%. Selanjutnya setiap 250 gram benih dikemas menggunakan kantong plastik ketebalan 0,8 $\mathrm{mm}$ dengan dua cara, yaitu secara konvensional (tidak kedap udara) dan kedap udara (vakum). Benih yang telah dikemas kemudian disimpan dalam 2 (dua) suhu yang berbeda, yaitu suhu ruang $\left(27-29^{\circ} \mathrm{C}\right)$ dan suhu dingin $\left(6^{\circ} \mathrm{C}\right)$. Pengamatan dilakukan setiap bulan untuk mengetahui kadar air, kondisi fisik benih, penyusutan berat, dan daya berkecambah. Data hasil pengamatan dianalisa secara statistik dengan analisa sidik ragam ANOVA dan dilanjutkan dengan uji Duncan tingkat kepercayaan 95\% (Steel dan Torie, 1993)

\section{HASIL DAN PEMBAHASAN \\ Kondisi Benih Awal Penyimpanan}

Sebelum dilakukan penyimpanan terhdap benih kedelai dilakukan pengujian benih awal meliputi kadar air, daya tumbuh benih, suhu dan kelembaban ruang simpan seperti tersaji dalam tabel 1.
Kadar air benih diatas $13 \%$ dapat meningkatkan laju kemunduran mutu benih selama penyimpanan. Laju kemunduran mutu benih dapat diperlambat, dengan cara kadar air benih harus dikurangi sampai kadar air benih optimum. Kadar air benih optimal, yaitu kadar air tertentu dimana benih tersebut disimpan lama tanpa mengalami penurunan mutu benih. Kadar air optimum dalam penyimpanan bagi sebagian besar benih adalah antara 6-11\%. Dari tabel 1 terlihat bahwa kadar air awal benih adalah $10 \%$ diharapkan benih tidak mengalami kemunduran mutu selama empat bulan penyimpanan.

Pada kondisi awal sebelum penyimpanan tiga varietas kedelai mempunyai daya tumbuh yang tinggi diatas 95\%. Secara statistic daya tumbuh tiga varietas benih kedelai sebelum penyimpanan adalah tidak berbeda nyata. Benih kemudian disimpan selama empat bulan, dan setiap bulan dilakukan pengamatan dan pengujian kualitas benih meliputi susut bobot, kadar air, daya tumbuh, serta keadaan fisik benih.

\section{Kadar Air Benih}

Benih kedelai yang disimpan dengan perlakuan tehnik pengemasan dan suhu ruang penyimpanan mengalami perubahan kadar air selama 4 (empat) bulan penyimpanan seperti terlihat pada gambar 1.

Dari gambar 1. Terlihat bahwa terjadi kenaikan kadar air setelah benih disimpan selama 4 (empat) bulan, hal ini terjadi karena terjadinya karena sifat biji kedelai yang hidroskopis, mudah menyerap uap air dari udara sekitar. Biji kedelai menyerap atau mengeluarkan zat air sampai kandungan airnya seimbang dengan udara sekitar. Jika dianalisa secara statistic dengan uji Duncan taraf kepercayaan 95\%, perlakuan tehnik pengemasan dan suhu ruang penyimpanan tidak memberikan pengaruh yang signifikan terhadap perubahan kadar air selama 4 (empat) bulan penyimpanan. Untuk mengetahui keeratan hubungan atau interaksi antara susut berat dengan kadar air benih kedelai perlakuan tehnik pengemasan dan suhu ruang penyimpanan selama 4 (empat) bulan dilakukan analisa statistic dengan uji korelasi taraf kepercayaan 95\% yang hasilnya tersaji dalam tabel .

Dari tabel 2. Terlihat tingkat keeratan hubungan atau interaksi antara susut berat dengan kadar air benih kedelai selama penyimpanan tidak begitu besar masih dibawah $20 \%$.

\section{Susut Berat}

Berdasarkan hasil pengamatan kondisi fisik benih kedelai sampai bulan ketiga penyimpanan masih bagus, tidak ditemukan adanya hama bubuk, hama bubuk mulai muncul pada penyimpanan bulan keempat pada perlakuan penyimpanan pada suhu 
kamar dengan tehnik pengemasan benih tanpa vakum. Hal ini terjadi karena pada tehnik penyimpanan tanpa kedap udara masih dimungkinkan adanya pertukaran udara dari dalam tempat penyimpanan benih dengan lingkungan sekitar sehingga memungkinkan hama bubuk untuk masuk dan berkembang biak. Tetapi populasi benih yang terkena hama bubuk relative sangat sedikit hanya sekitar $1 \%$.

Terjadi perubahan berat benih dari berat awal sampai benih mengalami proses penyimpanan dengan perlakuan tehnik pengemasan dan suhu ruang penyimpanan selama empat bulan. Perubahan berat benih setelah mengalami penyimpanan selama tiga bulan tersaji dalam gambar 2 .

Pada gambar 2 sampai 4 terlihat sebagian besar perlakuan mengalami penurunan berat. Perubahan berat ini berkaitan dengan perubahan kadar air selama penyimpanan. Dimana selama penyimpanan benih kedelai berusaha menyeimbangkan kandungan airnya dengan udara sekitar, mengingat sifat biji kedelai yang hidroskopis mudah untuk menyerap atau mengeluarkan air dari atau ke udara sekitar. Tetapi jika diuji secara statistic dengan uji regresi taraf kepercayaan 95\%, perubahan berat ini tidak signifikan dan dengan uji Duncan taraf kepercayaan 95\% tidak terlihat adanya beda nyata susut berat antara perlakuan penyimpanan selama empat bulan.

\section{Daya Berkecambah}

Untuk mengetahui keeratan hubungan antara perubahan susut berat terhadap kadar air benih kedelai selama 4 (empat) bulan penyimpanan dilakukan analisa regresi linier dengan metode backward (disajikan dalam tabel 3).

Dari tabel 3 terlihat bahwa susut berat dan kadar air selama 4 (empat) bulan penyimpanan dengan perlakuan pengemasan dan suhu ruang penyimpanan tidak begitu mempengaruhi (hubungan tidak erat) terhadap daya berkecambah benih kedelai. Hal ini terlihat pada nilai $\mathrm{R}$ dan $\mathrm{R}$ square yang dihasilkan. Pada bulan 1 hanya $0,6 \%$ susut berat mempengaruhi kadar air, bulan kedua 8,1\%, bulan ketiga 10,5\%, dan bulan keempat 31,4\%. Persentase daya berkecambah benih kedelai selama empat bulan penyimpanan dapat dilihat dalam gambar 3 .

Dari gambar 3. Terlihat daya berkecambah semua perlakuan setelah disimpan selam tiga bulan masih tinggi, diatas 90\%. Dengan tehnik penyimpanan secara vakum (kedap udara) dihasilkan rata-rata daya berkecambah yang lebih tinggi dan konstan dari pada tanpa vakum. Hal ini karena pengaruh luar (lingkungan) dapat diminimalkan sehingga proses deteriorasi dapat ditekan. Sedangkan dengan suhu penyimpanan rendah $\left(6^{\circ} \mathrm{C}\right)$ dihasilkan rata-rata daya berkecambah yang lebih baik dan konstan dari pada di suhu kamar Karena pada suhu rendah aktivitas enzim terutama enzim respirasi dapat ditekan. Kematian sel-sel meristimastis dan menurunnya cadangan makanan serta degradasi enzim dapat diperlambat sehingga viabilitas benih lebih tinggi.

\section{KESIMPULAN}

- Susut berat dan kadar air benih kedelai selama tiga bulan dengan perlakuan tehnik pengemasan dan suhu ruangan penyimpanan tidak memberikan pengaruh nyata terhadap daya berkecambah benih semua varietas.

- Penyimpanan benih kedelai selama tiga bulan dengan perlakuan tehnik pengemasan plastic kedap udara memberikan rata-rata daya berkecambah lebih baik dari pada tanpa vakum meskipun secara statistic dengan uji Duncan $\alpha=95 \%$ tidak berbeda nyata untuk semua varietas.

- Selama tiga bulan penyimpanan factor suhu ruangan belum berpengaruh terhadap daya berkecambah semua perlakuan.

\section{DAFTAR PUSTAKA}

1. Sadjad, S. 1980. Panduan Mutu Benih Tanaman Kehutanan Indonesia. IPB Bogor. 205p.

2. Steel, R.G.D. and J.H. Torrie, 1993. Principles and Procedures of Statistics. A Biomedical Approach, $3^{\text {rd }}$ Ed. Mc Graw Hill, Kagasukha Ltd., Tokyo.

3. Tatipata, A., Prapto Y., Aziz P., Woerjono P. 2004. Kajian Aspek dan Biokimia Deteriorasi Benih Kedelai Dalam Penyimpanan. Jurnal Ilmu Pertanian Vol. 11 No. 2, 2004. Halaman76-78.

4. Purwanti Setyastuti. 2004. Kajian Suhu Ruang Terhadap Kualitas Benih Kedelai Hitam dan Kuning. Jurnal Ilmu Pertanian Vol. 11 No. 1, 2004. Halaman 22-23.

5. Copeland, L. O. and M.B. Mc. Donald. 1985. Principles of Seed Science and Technology. Burgees Publishing Company. New York. 369p.

6. Kartono.2004. Tehnik Penyimpanan Benih Kedelai Varietas Wilis Pada Kadar Air dan Suhu Penyimpanan Yang Berbeda. Buletin Tehnik Pertanian Volume 9 Nomor 2 Tahun 2004.

7. Rumiati, S., Soemardi, Sukarman, dan M.F. Muhadjir. 1993. Teknologi Pengemasan Benih Kedelai Dengan Sistem Kedap Udara. Kinerja Penelitian Tanaman Pangan. Pusat Penelitian Dan Pengembangan Tanaman Pangan. Halaman $1472-1481$. 
Tabel 1. Hasil pengamatan kualitas benih awal

\begin{tabular}{lll}
\hline Parameter yang diamati & & Keterangan \\
\hline Kadar air & & $10 \%$ \\
Daya tumbuh benih & Varietas Burangrang & 96 \\
& Varietas Wilis & 98 \\
\multirow{2}{*}{ Suhu ruang penyimpanan } & Varietas Baluran & 100 \\
& Suhu kamar & $27-29^{\circ} \mathrm{C}$ \\
& Ruangan pendingin & $6^{\circ} \mathrm{C}$ \\
\hline
\end{tabular}

Tabel 2. Hasil analisa uji korelasi antara susut berat dengan kadar air selama 4 bulan penyimpanan benih kedelai dengan perlakuan tehnik pengemasan dan suhu ruang penyimpanan

\begin{tabular}{cc} 
Periode penyimpanan (bulan) & Nilai korelasi (\%) \\
\hline 1 & 16 \\
3 & 17,8 \\
4 & 4,9 \\
\end{tabular}

Tabel 3. Hasil analisa regresi linier dengan metode backward pengaruh susut berat dan kadar air terhadap daya berkecambah benih kedelai selama 4 (empat) bulan penyimpanan dengan perlakuan tehnik pengemasan dan suhu ruang penyimpanan

\begin{tabular}{cccc}
\hline Penyimpanan bulan ke- & $\mathrm{R}$ & R-square & Persamaan regresi \\
\hline 1 & 0,079 & 0,006 & $\mathrm{Y}=93,624+0,213 \mathrm{X} 1+0,08 \mathrm{X} 2$ \\
2 & 0,284 & 0,081 & $\mathrm{Y}=95,856+1,98 \mathrm{X} 1+3,358 \mathrm{X} 2$ \\
3 & 0,324 & 0,105 & $\mathrm{Y}=101,062-0,83 \mathrm{X} 1+0,05 \mathrm{X} 2$ \\
4 & 0,314 & 0,018 & $\mathrm{Y}=95,0800-0,32 \mathrm{X} 1+2,39 \mathrm{X} 2$ \\
\hline
\end{tabular}

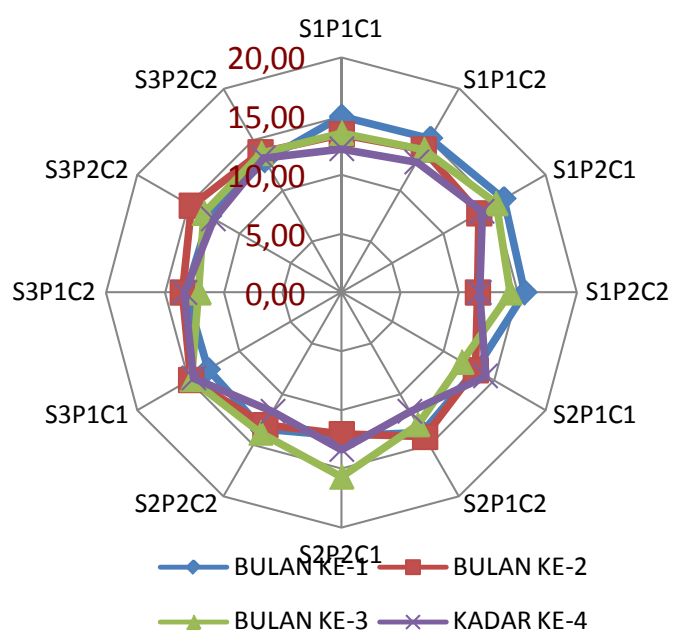

Gambar 1. Kadar air benih kedelai selama penyimpanan selama 4 (empat) bulan dengan perlakuan penyimpanan suhu ruangan dan tehnik pengemasan 


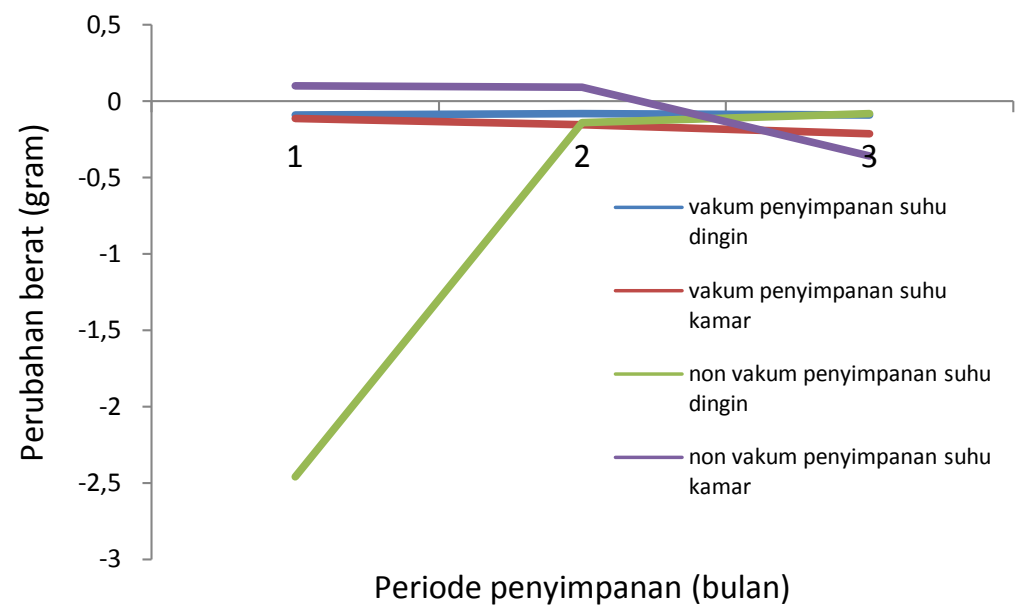

Gambar 2. Perubahan berat varietas Burangrang dengan tehnik penyimpanan vakum dan non vakum pada suhu kamar

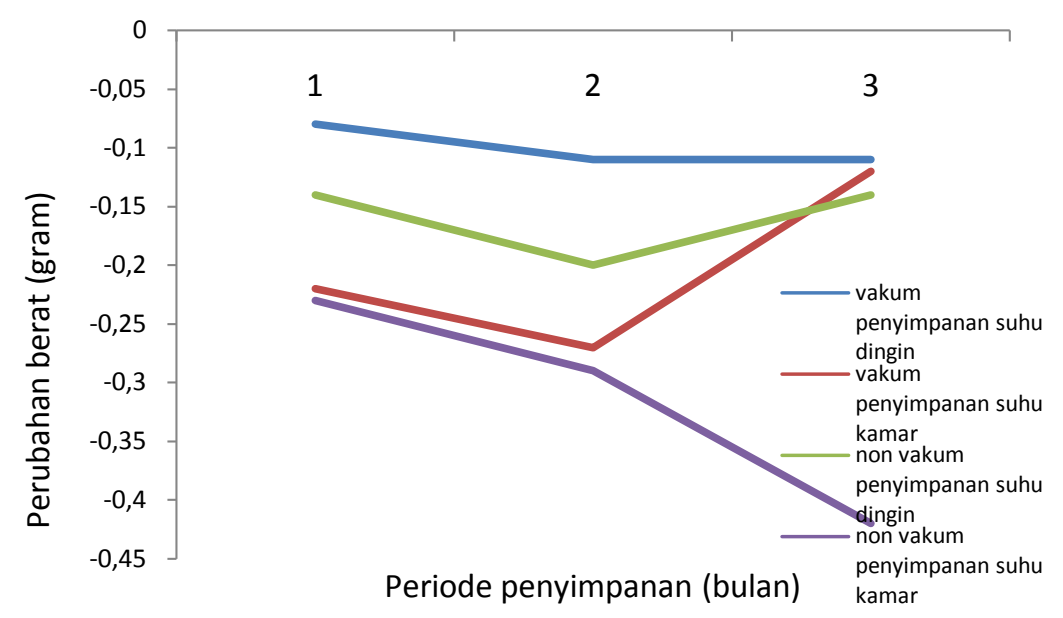

Gambar 3. Perubahan berat varietas Wilis dengan tehnik penyimpanan vakum dan non vakum pada suhu kamar dan dingin

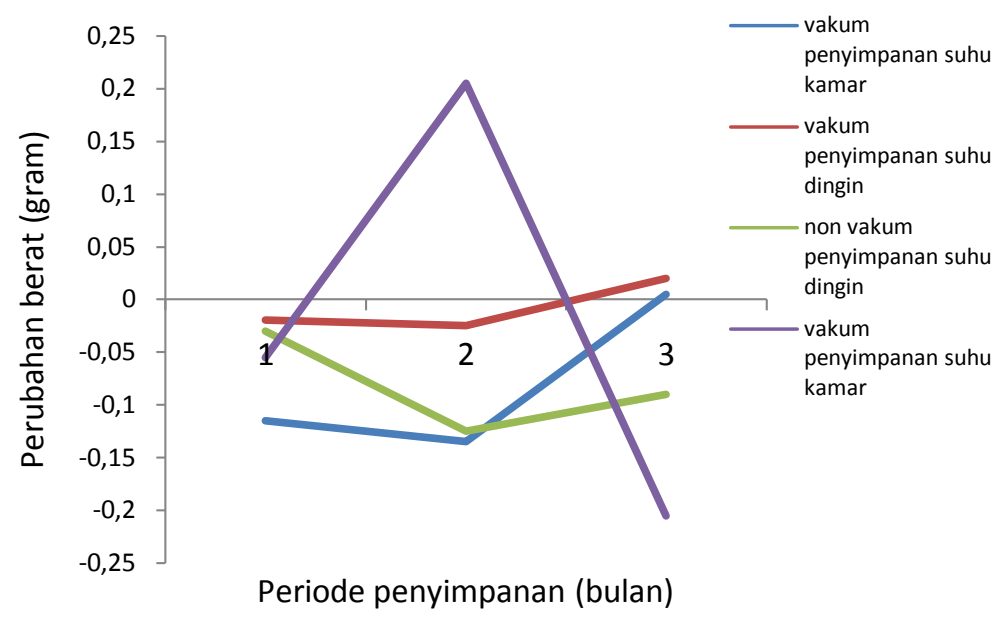

Gambar 4. Perubahan berat varietas Buluran dengan tehnik penyimpanan vakum dan non vakum pada suhu kamar 


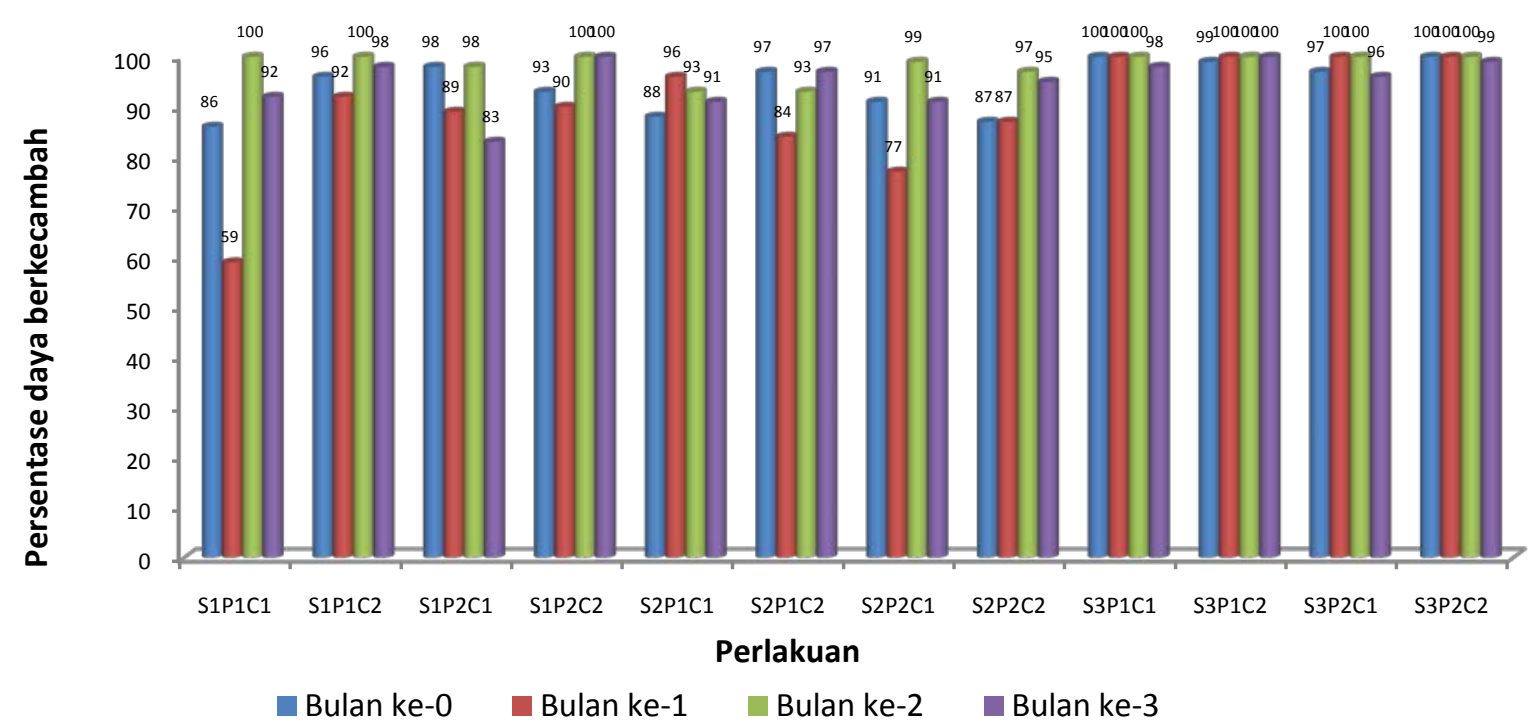

Gambar 5. Persentase daya berkecambah benih kedelai selama empat bulan dengan perlakuan tehnik pengemasan dan suhu ruang penyimpanan. 